\title{
A CORPUS-BASED APPROACH TO THE UKRAINIAN POLITICAL DISCOURSE STUDY
}

\section{Taran O. S.}

\section{INTRODUCTION}

Among various studies discussing different aspects of political discourse we had to mention some of them which use corpus-based approach. Mostly they are focused on American top-politician speeches (J. McCain, B. Obama, D. Trump, H. Clinton).

A number of papers by Jacques Savoy $(2010,2016)$ describe a US political corpora and present the study of the style and rhetoric of John McCain \& Barack Obama ${ }^{1}$, Hillary Clinton \& Donald Trump ${ }^{2}$ during presidential elections. To detect and analyze differences between Trump and Clinton, the author examined both the oral communication form and the written form of the last. Asomwan Adagbonyin, Isaiah Aluya \& Samuel Edem (2016) described a corpus-based approach to identify the linguistic devices used in Nigerian and American presidential speeches. Authors compared both presidents' usage of linguistic devices in terms of frequency at the levels of keyword, part of speech and semantic domain as well as the communicative purpose which the linguistic devices serve $^{3}$. Valentin Kassarnig (2016) presented an approach of training a system on speech transcripts in order to generate new speeches for a desired political party. A simple statistical language model based on 6-grams was used ${ }^{4}$. Interesting results of $\mathrm{N}$-gram-based method of a presidential debate transcript analysis were presented by Daniel Walter's $(2016)^{5}$.

1 Savoy J. Lexical Analysis of Obama's and McCain's Speeches. Journal of Quantitative Linguistics. 2010. № 17(2). P. 123-141. DOI: 10.1080/09296171003643205.

2 Savoy J. Trump's and Clinton's Style and Rhetoric During the 2016 Presidential Election. Journal of Quantitative Linguistics. 2016. DOI: 10.1080/09296174.2017.1349358.

${ }^{3}$ Adagbonyin A, Aluya I. Edem S. A corpus-based approach to the linguistic features in Nigerian and American presidential speeches. Journal of Linguistics, Language and Culture. 2016. Vol. 3. № 1. P. 1-27.

${ }^{4}$ Kassarnig V. Political Speech Generation // eprint arXiv:1601.03313 (January 2016). URL: https://arxiv.org/abs/1601.03313.

${ }^{5}$ Walter D.A Presidential Debate in N-grams // Subjective Functions: blog (published: Wed 28 September 2016). URL: https://dswalter.github.io/. 
Ukrainian political discourse studies usually dill with the methods of traditional linguistics and manual approaches to establish particular properties of political contexts, structure and lexicon, syntax and rhetoric, speech acts and interaction. We can mention only a few researches in which corpus-based approached was applied, such as: Margaryta Dorofeyeva (2005) studied category of subject in Federal chancellors' political speech ${ }^{6}$, Dariia Kharytonova (2019) investigated cognitive and pragmatic dimensions of Ukrainian political discourse ${ }^{7}$. But governmental or parliamentary speeches or presidential programs were not studied jet, also there are no corpus-based studies of them, what emphasizes the urgency of this paper.

There are a lot of classifications of discourse type. For example, according to ideological stances political discourse subdivides into LGBT discourse, religious, green, nationalistic, feminist. All of them represent a discourse of a particular segment/group of society ${ }^{8}$. It is one of the Teun van Dijk's ideas interpretation ways: "Since people and their practices may be categorized in many ways, most groups and their members will occasionally (also) 'act politically', and we may propose that 'acting politically', and hence also political discourse"”.

Political discourse is subdivided according to different denominations: spoken or written; prepared or spontaneous speech; spoken monologue or dialogue / polylogue. Representatives of each show different genres: biography of a politician, slogan, political program, campaign text, ritual speech etc. ${ }^{10}$ Parliament speech and ritual speech are both monologues but they are delivered to a different audience. In the first case it is a commonly homogeneous type of recipients - government officials and also the media, in the second one speech is aimed at a large heterogeneous audience. These different types are reflected in corpora: governmental corpora (Labbé \& Monière), electoral corpus (Jacques Savoy). None of open corpora

6 Дорофєєва М.С. Категорія суб'єкта в політичній промові (на матеріалі виступів федеральних канцлерів ФРН повоєнного періоду) : автореф. дис. ... канд. філол. н. : 10.02.04. Київ, 2005. 23 с.

${ }^{7}$ Харитонова Д.Д. Український політичний дискурс: когнітивно-семантичні та прагмакомунікативні виміри : дис. ... канд. філол. н. : 10.02.01. Київ, 2018. 212 с.

${ }^{8}$ Amaglobeli G. Types of Political Discourses and Their Classification. Journal of Education in Black Sea Region. 2017. Vol. 3. Issue 1. P. 18-24. DOI: 3. 10.31578/jebs.v3i1.117.

${ }^{9}$ Dijk T.A. van What is Political Discourse Analysis? URL: http://www.discourses.org/OldArticles/What\%20is\%20Political\%20Discourse\%20Analys is.pdf.

${ }^{10}$ N. Kondratenko's monograph examines certain genres of political discourse; political program, TV debates, New Year's greetings and inaugural speeches of presidents [13]. 
developed for the Ukrainian language contains the governmental or parliament speeches.

For this study presidential programs as a type of written discourse (section 1) and parliament speeches transcripts (section 2) as an oral text genre were chosen. The main goal of this paper is to distinguish linguistic features of each type of mentioned discourse which the corpus-based approach can reveal.

\section{Presidential programs}

The 2019 presidential election in Ukraine was characterized by two figures: Volodymyr Zelenskyi and Petro Poroshenko who won the presidential election in 2014 but lost 2019 election to his opponent. So, that's why their presidential programs were chosen for analysis in this research paper. The programs were downloaded from official website of The Central Election Commission of Ukraine ${ }^{11}$. Further work was done using NLP tools for quantitative analysis of text. For this we removed quotes and dashes from the texts of both programs. Uppercase was ignored.

\subsection{Keywords}

At the first stage of the study we focus on word occurrence frequencies. Software TextusPro $1.0^{12}$ allows to receive a list of keywords without stopwords which are usually the most frequent (conjunctions, prepositions, particles etc.). As a result, we can see tokens sorted by absolute frequency (AF) and relative frequency according to free stop-words text $\left(\mathrm{RF}_{\text {stop }}\right)$. As the Ukrainian language is an inflectional language we had to lead similar tokens to lemmas. Thus with manual search we sorted lemmas taking into account phonetic alternations in suffixes. In such way we received semantic hard core of each presidential program. Comparison of key lemmas in both presidential programs allows to find out common concepts (fig. 1), which represent meaningful topics.

Figure 1 shows relative frequency according to free stop-words text. As we can see, the most significant concept in both programs is Україн-

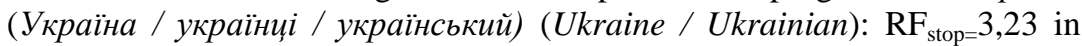
Zelenskyi's program and 3,14 in Poroshenko's program.

We chose 10 lemmas with $\mathrm{AF} \geq 4$ for each presidential program and compared two lists. Tables 1, 2 present distinctions in frequency of key lemmas in both presidential programs.

\footnotetext{
${ }^{11}$ URL: https://www.cvk.gov.ua.
}

${ }^{12}$ TextusPro is a freeware for text SEO-optimization, it makes elementary statistical analysis of text. Available from: http://rabota-kopirait.com/index/textus_pro/0-196. 


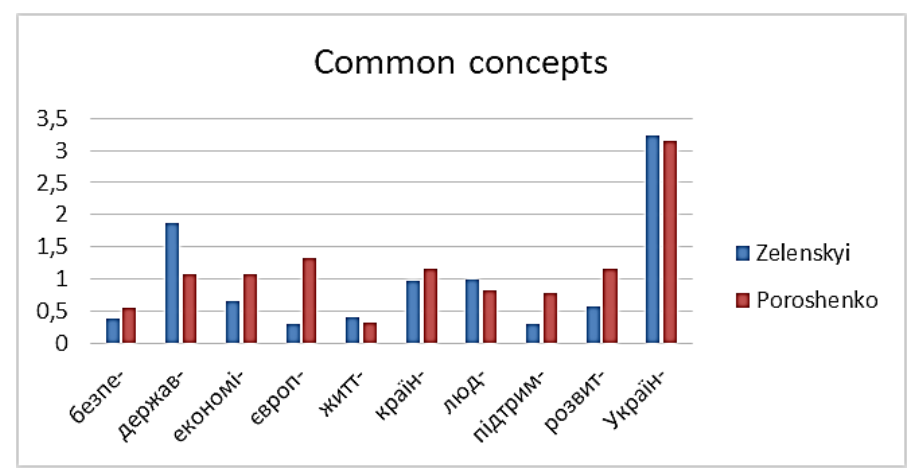

Fig. 1. Common concepts in both presidential programs

Different key lemmas in Zelenskyi's program

\begin{tabular}{|c|c|c|c|c|}
\hline Rank & $\begin{array}{c}\text { Key lemmas in } \\
\text { Zelenskyi's } \\
\text { program }\end{array}$ & $\mathbf{A F}$ & $\mathbf{R F}_{\text {stop }}$ & $\begin{array}{c}\text { AF in Poroshenko's } \\
\text { program }\end{array}$ \\
\hline 1 & народ- & 14 & 0,97 & 1 \\
\hline 2 & освіт- & 14 & 1,13 & 3 \\
\hline 3 & влад- & 12 & 0,97 & 1 \\
\hline 4 & бізнес- & 8 & 0,65 & 1 \\
\hline 5 & корупиі- & 7 & 0,57 & 3 \\
\hline 6 & майбут- & 7 & 0,57 & 0 \\
\hline 7 & вибор- & 4 & 0,32 & 1 \\
\hline 8 & здоров- & 4 & 0,32 & 0 \\
\hline 9 & президент- & 4 & 0,32 & 0 \\
\hline 10 & справедлив- & 4 & 0,32 & 0 \\
\hline
\end{tabular}

The contents of the tables illustrate some interesting points. At first, it is obviously, the most frequent lemmas reveal the most important concepts in presidential programs. Semantic analysis of the main concepts of Zelenskyi's program shows that they are connected to terms of internal policy such as priority areas, as problems. The text of Poroshenko's program is focused on both external policy (joining NATO and the EU) and internal policy. The second point is extremely different frequency of key lemmas. It means that the most important concepts in Poroshenko's program have low frequency or zero 
rate in Zelenskyi's program and vice versa. The key words of Porohenko's political slogan - 2019 армія - церква -мова (army - church-language) are absent among frequent key words in his presidential program, all of them have AF 1. There are no such concepts in his program as: майбутне / майбутній, вибори, президент, справедливість / справедливий (future, elections, president, justice). But Zelenskyi doesn't speak about вільний, змога / змогти, підвищення / підвищений (free, able, raised).

Table 2

Different key lemmas in Poroshenko's program

\begin{tabular}{|c|c|c|c|c|}
\hline Rank & $\begin{array}{c}\text { Key lemmas in } \\
\text { Poroshenko's } \\
\text { program }\end{array}$ & $\mathbf{A F}$ & $\mathbf{R F}_{\text {stop }}$ & $\begin{array}{c}\text { AF in Zelenskyi's } \\
\text { program }\end{array}$ \\
\hline 1 & можлив- & 10 & 0,77 & 2 \\
\hline 2 & захис- & 8 & 0,61 & 1 \\
\hline 3 & вільн- & 6 & 0,5 & 0 \\
\hline 4 & НАТО & 6 & 0,5 & 1 \\
\hline 5 & СС & 5 & 0,38 & 3 \\
\hline 6 & змог- & 5 & 0,38 & 0 \\
\hline 7 & інфраструктур- & 5 & 0,38 & 2 \\
\hline 8 & підвищен- & 5 & 0,38 & 0 \\
\hline 9 & щаслив- & 5 & 0,38 & 1 \\
\hline 10 & окупован- & 4 & 0,31 & 1 \\
\hline
\end{tabular}

\subsection{Pronouns}

Quantitative parameters of pronouns in political speech allow to reveal hidden intentions. For example, according to a corpus-based research, "Obama's use of the personal pronouns "she", "he" and "they" suggests references beyond himself and indicate the level of difference in the distance from the electorates observes"13.

Quantitative measurements of pronouns in presidential programs which introduce written speech genre reveals tactics of the self-presentation strategy of presidential candidates. We used the classification proposed by Marina Dorofeeva: tactics of singularity, tactics of plurality, tactics of

${ }^{13}$ Adagbonyin A, Aluya I. Edem S. A corpus-based approach to the linguistic features in Nigerian and American presidential speeches. Journal of Linguistics, Language and Culture. 2016. Vol. 3. № 1. P. 1-27. 
indefiniteness, tactics of elimination ${ }^{14}$. Fig. 2 and fig. 3 show percentage of each pronoun among all pronoun tokens used in the text. On this stage of our study the software AntConc $3.4 .4 \mathrm{w}^{15}$ was used.
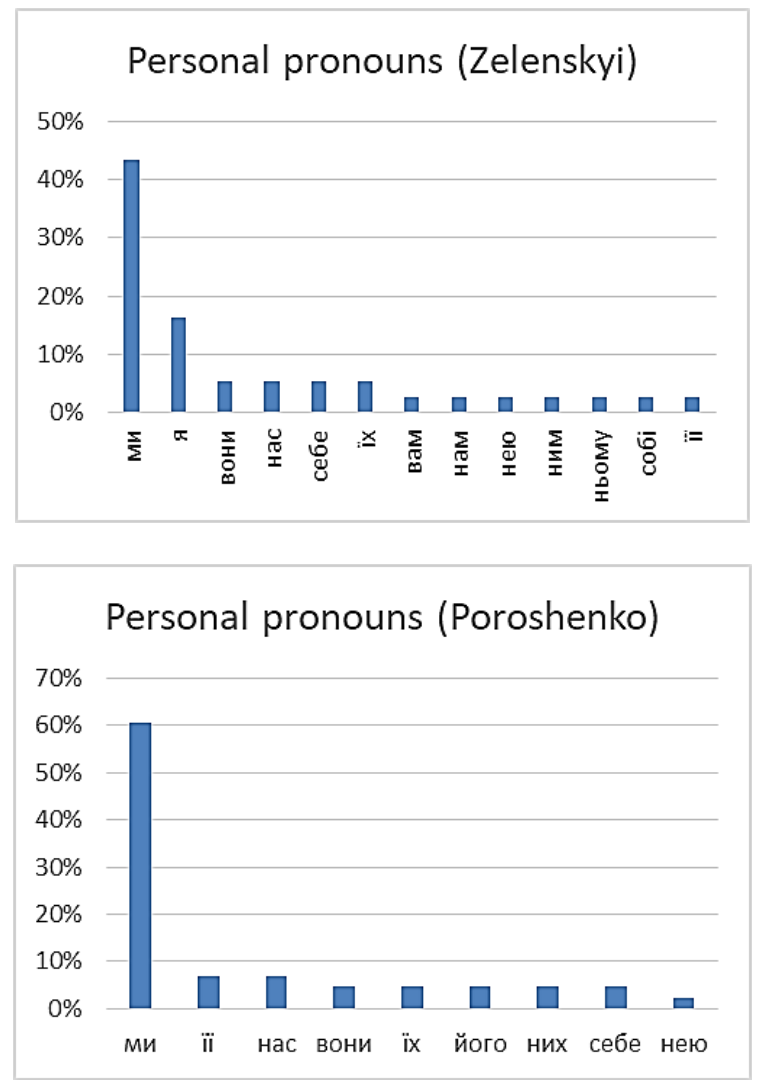

Fig. 2, 3. Percentage of personal pronoun tokens in presidential programs

14 Дорофєєва М.С. Категорія суб'єкта в політичній промові (на матеріалі виступів федеральних канцлерів ФРН повоєнного періоду): автореф. дис. ... канд. філол. н.: 10.02.04. Київ, 2005. 23 с.

15 AntConc is a free corpus manager for concordancing and text analysis, available from: http://www.laurenceanthony.net/software/antconc/. 
In general, Poroshenko used pronoun tokens a bit more than Zelenskyi: 5\% and $4 \%$ respectively. But their number is less: 9 pronoun tokens in Poroshenko's program against 13 pronoun forms in Zelenskyi's text. Figure 4 shows relative frequency (RF) of pronoun lemmas (e.g., the lemma ми (we) includes forms нас, нам (us) etc.). If we compare lemmas in both programs we'll see that Poroshenko used only 5 pronouns, Zelenskyi used 7 pronouns.

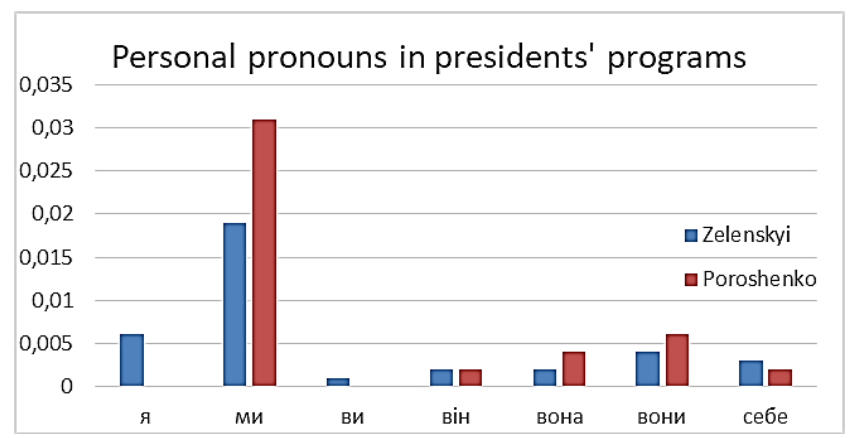

Fig. 4. RF of personal pronoun lemmas in presidential programs

Also, we have compared percentage of pronouns used in both Poroshenko's presidential programs $2014 \& 2019$ and noticed such feature: in 2014 his program contained pronouns $я(I)-11 \%, в и($ уои $)-7 \%$. Usage of personal pronoun $\Omega(I)$ points to singularity tactics. It is an active tactic of direct self-presentation. But in 2019 Poroshenko's team refused of it.

In both presidential programs the most frequent pronoun is $\boldsymbol{м u}(w e)$ and it indicates tactics of plurality. This tactic is realized in metonymy "we = I + my team", "we = I + my sympathizer / my electorate", "we = I + you / addressee / a people". In the first case, the metaphor states that the responsibility for the words lies on the speaker's team. In the second and third cases, the level of responsibility of the speaker for his own statements is significantly lower, as the responsibility for decision-making is transferred to the listener.

An interesting fact related to the frequencies of the pronoun we in American political discourse was pointed by Jacques Savoy: "The written form tends to use the we more frequently than the $I$. The pronoun we owns the useful advantage of being ambiguous (who is really behind the we? Myself and the future government? Me and the people? Me and the workers? Me and 
the (future) Congress? etc.)"16. A similar observation was made by Concepción Hernández-Guerra in her research of the Barack Obama's speech: "Moving on to something else, the wide use of the pronoun "we" referring to different addressees may be done purposely to involve everybody indirectly in the solution of the problems or to reflect that everybody is responsible of the problems that threaten the world, not just America" 17 .

It is interesting to trace in what collocations pronoun $м u$ (we) were used by Poroshenko and Zelenskyi.

\subsection{N-grams}

The $\mathrm{N}$-grams option (with $\mathrm{min} / \mathrm{max}$ cluster size $=3$ ) of AntConc $3.4 .4 \mathrm{w}$ allows to find 3-grams which contain pronoun $м u$ (we).

There are 163 -grams in Zelenskyi's program, which are presented in the table 3. All of them have $\mathrm{AF}=1$. As we can see, $69 \%$ of them are constructions with verb in the Future tense, only $6 \%$ contains the verb in the Past tense and $13 \%$ have modal verbs. So as V. Zelensky ran to presidential election for the first time and he had no experience in politics he appealed to the future. One of 3-gram explains what does $м и$ (we) mean: ми ие народ (we are a people).

Table 3

\section{List of 3-grams in Zelenskyi's program}

\begin{tabular}{|c|c|}
\hline ми будемо питатись & ми сприятимемо розвитку \\
ми відкриємо украӥнський & ми ставитимемо питання \\
ми забезпечимо монетизацію & ми створимо умови \\
ми запровадимо одноразову & ми повинні вибороти \\
ми запровадимо принцип & ми повинні замінити \\
ми перестанемо концентрувати & ми плекали на \\
ми повернемо довіру & ми це народ \\
ми разом закріпимо & ми і вони \\
\hline
\end{tabular}

${ }^{16}$ Savoy J. Trump's and Clinton's Style and Rhetoric During the 2016 Presidential Election. Journal of Quantitative Linguistics. 2016. DOI: 10.1080/09296174.2017.1349358.

${ }^{17}$ Guerra C.H. Textual, intertextual and rhetorical features in political discourse: the case of President Obama in Europe. Revista de Lingüistica y Lenguas Aplicadas. 2013. № 8. DOI: 10.4995/rlyla.2013.1175. 
We received results of N-gram analysis of Poroshenko's program which indicate about different from Zelenskyi strategy of self-presentation. They are reflected in the table 4.

Table 4

List of 3-grams in Poroshenko's program

\begin{tabular}{|c|c|}
\hline ми вступимо як & ми відродили армію \\
\hline ми гармонізуємо структуру & ми заклали міцний \\
\hline ми забезпечимо активну & ми захистили наш \\
\hline ми завершимо створення & ми зробили те \\
\hline ми збільшимо обсяги & ми отримали безвіз \\
\hline ми подамо заявку & ми прорвали російську \\
\hline ми продовжимо децентралізаџію & ми підписали угоду \\
\hline ми продовжимо лінію & ми створили потужну \\
\hline ми продовжимо ичю & ми захищаємо свою \\
\hline ми піднімемо рівень & ми можемо вийти \\
\hline ми робитимемо усе & ми спрямуємо зусилля \\
\hline ми сприятимемо перетворенню & ми краӥна, яка \\
\hline ми повинні зосередити & ми й надалі \\
\hline
\end{tabular}

There are 26 3-grams, all of them have AF=1. In Poroshenko's case we found out more variety tense forms of verbs in 3-grams: $46 \%$ contains verbs in the Future Tense, $12 \%$ is in the Present tense, $31 \%$ is in the Past tense and $4 \%$ have modal verbs. It is obvious, candidate appeals to positive experience and achievements but also he builds a chain of events "past - present -

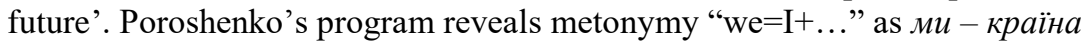
(we are country), which is wider and more indefinite because includes not only people but state structures, territory, resources etc.

At the last stage of presidential program study we wanted to know whether there were phrases that popped up frequently for each candidate. For this purpose, we analyzed $\mathrm{N}$-grams for $\mathrm{n}=2 \ldots 10$ whether there were repeated phrases. This analysis appeared an interesting point about syntax.

The maximum repeated cluster size in Zelenskyi's program is 4. As we can see from the list of 4-grams (table 5), Zelenskyi used opposite constructions (1,2\% from total number of 4-Gram types 1590). 
List of 4-grams in Zelenskyi's program

\begin{tabular}{|c|c|}
\hline а в польщчі & а не системою забаганок \\
а всі решта знати & а не те щзо \\
а дурнів немає цее & а не інфаркт від \\
а корупціонери реальні строки & а перемога над нею \\
а не депутати де & а переходитимуть у спадиину \\
а не з вікон & а повинен забезпечити гідні \\
а не людина для & а проголосувати на виборах \\
не лікувати програма & а тепер про те \\
а не на десятьох & ахто не зрозумів \\
ане прислужником $у$ & \\
\hline
\end{tabular}

Obviously such constructions were used to emphasize a difference between reality and proposing perspective. Repetition of the opposite constructions has a suggestive effect, like any repetition.

The maximum repeated cluster size in Poroshenko's program is also 4. In Poroshenko's program we have find only three 4 -grams $(0,2 \%$ from total number of 4-gram types 1541) which indicated contrastive constructions (table 6).

Table 6

List of 4-grams in Porosheno's program

\begin{tabular}{c|}
\hline а й всю європейську \\
але справжнє лідерство можливе \\
але щоб стати справжнім \\
\hline
\end{tabular}

So, using NLP tools for quantitative method of text analyses allows to appear some interesting linguistic features about tactics and strategies of presidential programs which are not evident with manual research.

\section{Ukrainian Parliamentary speeches}

Speech in Ukrainian Parliament is a kind of formal communication. Often it combines prepared and spontaneous spoken monologue. The first addressee is deputies and government official and then the media which interprets parliament events for wide audience. All these facts determine the politician's strategies and tactics and, of course, their linguistic features. 


\subsection{Corpus}

For this stage of our study we created a corpus of transcripts of parliamentary speeshes in 2004-2021, i.e. the parliament from IV to IX convocation. Transcripts had been downloaded from official site of Ukrainian parliament Verkhovna $\operatorname{Rada}^{18}$. We employed a commercial corpus management and corpus query software SkethEngine ${ }^{19}$. Figure 5 reports our corpus text size.

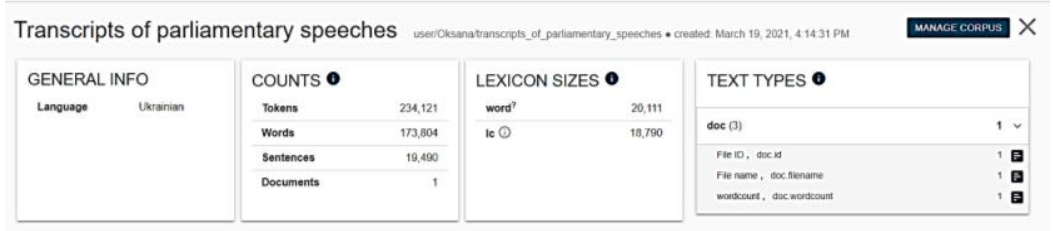

Fig. 5. Corpus statistics

The Keywords option allows to find as the most frequent tokens in compare with reference corpuse as rare or unusual words in our corpus which is focus corpus. Ukrainian Web 2014 (ukTenTen14) amounting to 1388494043 tokens was chosen as the reference corpus. In order to perform this task advanced settings were used. Non-words (tokens which do not start with a letter of the alphabet) were excluded.

According to the average reduced frequency (ARF), words of etiquette are in the top-20 of the most frequent: прошу, будь ласка (please), дякую (thank уои), иановні (dear) as well as the vocative колеги (colleagues). It indicates a certain degree of ritual speech in Ukrainian parliament. The next analysis was focused on rare words. It is a list of tokens with $\mathrm{AF}=1 \ldots 3$ in the focus corpus (i.e. Transcripts of parliamentary speeches corpus) and $\mathrm{AF}=0$ in the reference corpus. It allows to find out some linguistic features of Ukrainian formal parliamentary speeches:

1) surzhykisms (несостиковки, юморить, южаніної, вскривав, полистаєте, видвинута, присвоїте, обідняємо, согласловували, взривами, спросіть, сотрясати, запретити, заранєє, просовуєте, виясняв, присилала, розгрузити) reflect very poor Ukrainian language skills of politicians;

\footnotetext{
${ }^{18}$ URL: https://www.rada.gov.ua.

${ }^{19}$ URL : https://app.sketchengine.eu/.
} 
2) Russian words which are in Russian graphics (оспоренныцй, выкидая, услышиан, привыкали, воспалённом, барышня) reflect Russian speeches of some deputies who do not speak Ukrainian;

3) осcаsionalisms (юридизм, єврооптимісти, профіртамівська, Мінздох) provide evidence of language creativity;

4) barbarisms (Maruv, ProZorro, Bihus.info, ICTV) declare a tendency of using Latin graphics for proper names;

5) gender forms (міністерка, колежаниі) gradually enter into speech of lawmakers, who are predominantly male;

6) colloquialisms (обналом, есбеушні, блефуєте, говорильнею, шо-то, кацапи, компашка, платіжка, претесь, здох) and slang vocabulary (сєпар, гонітє, вибиваємо, совдепівські) indicate from one hand, cultural and educational level of politicians but from another hand, their communicative tactics. Slang which can be used only in informal communication but not in professional speeches in Ukrainian parliament, became the subject of our research in the next section.

\subsection{Slang}

$\mathrm{N}$. Kondratenko says that fashion in language violates normative requirements, and politicians are the subjects of language fashion creation in political discourse ${ }^{20}$. During Trump's term a lot of media (e.g. The New York Times, Salon, Fortune, The New Yorker, The Washington Post) discussed his "rhetorical strategy to gain popularity, in accordance to the trend of anti-intellectualism" 21 .

We distinguish political slang and common slang usage of which are understandable to everybody despite out of social stratification. In the first case we deal with professional slang (or jargon) which is used in informal communication of politicians. But some units of political slang can be spread via media to society (e.g. ширка - broad coalition, піаніст, кнопкодав - a deputy who votes in the parliament with someone's card, противсіx - a voter who chooses the line "against all" in the ballot). Ukrainian politicians use both slangs.

Earlier we were studying slang in informal communication of Ukrainian deputies, in particular during talk-show ${ }^{22}$, which made it possible to observe

20 Кондратенко Н.В. Український політичний дискурс: Текстуалізація реальності: монографія. Одеса: Чорномор'я, 2007. 156 с.

${ }^{21}$ Kayam O. The Readability and Simplicity of Donald Trump's Language. Political Studies Review. 2018. Vol. 16. Issue 1. P. 73-88. DOI: 10.1177/1478929917706844.

${ }^{22}$ Таран O.С. Сугестивні потенції сленгізмів в українських дискурсах. Ucrainica VI. Současná Ukrajinistika. Problémy jazyka, literatury a kultury: Sborník vědeckých článků. Olomouc: Univerzita Palackého v Olomouci, 2014. P. 168-171. 
the unprepared oral speech of politicians, its proneness to conflict, expressiveness, evaluativity, often substandart language elements. In such case the addressee was political opponents, the direct audience in the studio of talk-show and the mass addressee.

As L. Morawskinotes that political discourse is not aimed at dialogue ${ }^{23}$. So, it is always monologue with two main strategies: self-presentation and discrediting the opponent. From these points we analyzed slang in deputies' speech in the parliament.

First of all, the self-presentation strategy is realizing in tactics of demonstration of power and authority. And argot usage helps in it. This tradition of criminal argot usage has been inherited since Soviet Union, since 1917 when the revolutionaries used the vocabulary of the lowest strata of society to show prestige of proletarian language against the language of the clerisy. In the 70's of the XXth century there was an amalgamation of top managers of the USSR and the criminal world. This co-operation has had new perspectives after the collapse of the USSR and in the conditions of an independent Ukraine. Also, there were common interests of members of political and criminal circles. M. Nadel-Chervinska \& A. Chervinska use R. Barthes' term "sadic language" for marking a communicative form of the "Soviet zone" which arose as a result of the interaction of prison argot with administrative \& political jargon ${ }^{24}$. If in the Soviet times the "sadic language" existed mainly in the colloquial informal sphere (in such communicative situations as 'boss - subordinate'), then after the collapse of the USSR it came into widespread usage on the background of general criminalization of society and colloquialization of the Ukrainian language. The socio-psychological habit of politicians to use argot vocabulary of the power vertical manifests itself to this day. Usage of argot in formal communication may be unconsciously.

The most frequent argot words are: дерибан, дерибанити, криша, кришувати, блатний, бєспрєдєл, вибити, відмазати, відмивати, відмивання, втюхнути, гнати, зачистити, наїзд, розборка, розвести / розводити, розвод, лох, also lexemes with meaning of sexual violence used as metaphor: прогнутися, нагнути. Now all of them comes into common

Таран О.С. Сленгизмы в политическом дискурсе (на материале украинских телевизионных ток-шоу). Вестник Прикамского соииального института. Филология. Пермь, 2013. № 2 (60). С. 42-48.

${ }^{23}$ Morawski L. Argumentacje, racjonalność prawa i postępowanie dowodowe. Torun : Universytet Mikołaja Kopernika, 1988. 311 s.

${ }^{24}$ Надель-Червинская М., Червинская А. Язык и сознание: номенклатура и феня (уголовно-партийный жаргон как коммуникативная форма «советской зоны»). Тернополь : Studia methodologica, 2009. 102 с. 
informal use, we call it as common slang. But speakers feel argotic origin of them.

We noticed that slang (mostly of argotic origin) were used by every chairman of Ukrainian parliament on the sessions of 2004-2021:

- Ну, скажімо, ми, дійсно, вдається нам вибити оці гранти $i$ одержати надзвичайно дороге обладнання, але коли воно приходить сюди, воно зустрічає неймовірні перепони (Volodymyr Lytvyn, 30.01.2004);

- Iде боротьба не про ставлення до влади, іде боротьба за доступ до газової труби, за “кришування” ПДВ (Oleksandr Moroz, 27.09.2007);

- ...бажано, щоб трагічні історичні факти не втягувалися в зовнішньополітичні “розборки” між двома державами (Arsenii Yatseniuk, 4.04.2008);

- Розвели, насамперед, мене. Але, за великими рахунком, розвели Украӥну, розвели народ (Volodymyr Lytvyn, 4.07.2012);

- ...внутришньопартійні розборки (Volodymyr Rybak, 22.02.2013);

- ... щоб пільгами не користувалися шахраї, які отримали відповідні документи «завдяки якомусь “блату” чи зв'язкам (Oleksandr Turchynov, 31.10.2014);

- ...закон, який дозволить правильно побудувати систему адміністративних послуг, $i$ цю пострадянську систему, де все вирішувалося по блату, вона взагалі буде скасована иими законами (Volodymyr Hroisman, 26.11.2015);

- Змінами до чинного законодавства ми ліквідували гігантську корупиійну схему - “відкати” при поверненні податку на додану варmicms (Andrii Parubii, 5.07.2019);

- Завжди є частина суспільства, якій “треба більше за всіх”. Їй потрібно більше драйву, більше активностей, ї̈ бентежать ті чи інші проблеми (Dmytro Razumkov, 22.02.2021).

So, it is expected that argot is used by official establishment such as prime-minister, ministers, general prosecutor etc:

- В іншому випадку ті, хто спричинив чергову політичну кризу та ситуацію “безголового” парламенту, мають разом із Президентом брати відповідальність на себе $i$ “не розводити” ні парламент, ні усю країну (M. Tomenko, vice speaker of the parliament, 18.11.2008);

- Підтримку з метою саме виконати їх, а не з метою “з'йхати” 3 їх виконання (P. Klimkin, the minister for external affairs, 13.02.2015);

- Також були зірвані ще ряд спецоперацій, одна з яких стосувалася “кришування” грального бізнесу, до якого, за його словами, також були причетні праиівники СБУ (A. Sytnyk, the head of National Anti-Corruption Bureau, 3.10.2018); 
- Виконувати свої обов'язки добросовісно, чесно і сумлінно. Не продавати справи, не “зливати” їх, не повертати прокурорських перевертнів (I. Venedyktova, the General prosecutor of Ukraine, 17.03.2020).

Slang words, especially slang of argot origin, are sociolinguistic markers in the linguistic portrait of politicians. The subconscious choice of such vocabulary is an implicit demonstration of power and authority. It is the ways of self-affirmation.

The strategy of self-presentation of politicians is also realized in tactics of approaching to people via use of slang as a "source of linguistic realism" (expression by $\mathrm{O}$. Taranenko). The aim of the tactics is to reduce the distance between the politicians and the addressee, who have different social and material status, and accordingly - to reduce the critical perception of the image of a politician:

- ...місто перетворилось в руїну: розриті дороги, утворились фіктивні управительські фірми, дерибан землі, бардак (М. Burbak, 23.04.2019);

- Ми намагаємося прогнутися перед всіма (O. Musii, 14.03.2019);

- I реакиія їх дуже проста, молодіжна: шо ви гоніте? (S. Kaplin, 5.02.2019);

- ...прибрати з наших доріг мажсорів, блатних, всяких чиновників, які замість того, щоби мати дозвіл на такі сигнали, сують в обличчя співробітнику мілічії корочку - оце для них головний дозвіл (S. Mishchenko, 4.03.2015).

In these examples, slang is also marker of language outrageous.

The main intention of political discourse is the struggle for power. So, the next important strategy is discrediting the opponent. It is realized with tactics of lowering the political status of the opponent via conscious use of argot origin words and phrases for his personal characteristics, description of his actions, contacts and professional activities:

- Вже третю добу країну по суті в шоиі тримає інформація про те, щчо завод Президента України - Головнокомандувача краӥни відмивав кошти через “Ленінську кузню” (Yu. Tymoshenko about P. Poroshenko, 28.02.2019);

- Юлія Тимошенко вже пообічяла “відмазати” його від звинувачень, якщо стане Президентом (A. Herasymov about Yu. Tymoshenko, 12.03.2019).

Using argot, a speaker hints at the connection of his opponent with the criminal subculture to which society has a persistent negative attitude. Argot is a "specific sign of aggression" (expression by O. Sheigal) because it acquires the ideological connotation of stranger. Professional jargon units 
used to describe an opponent's actions may have the same sarcasm effect like in such contexts with military jargon units:

- ...ну, не ведіть себе так, як ви виглядаєте шнурком в офічерських бериах полічейської держави (V. Nimchenko, 23.04.2019);

- він лише підтвердить, що сам просто “відкосив" від порятунку краӥни (A. Herasymov, 23.04.2019).

As we can see, in all examples slang (argot) was used for describing a political opponent, his/her ideology, his/her activity explicitly or implicitly. In such way archetypal binary opposition 'my - stranger' is realized.

\section{CONCLUSIONS}

Corpus-based approach allows the quantitative analysis which deals with occurrence frequency, quantitative parameters of pronouns and $\mathrm{N}$-grams of Zelenskyi's and Poroshenko's presidential programs. The result shows that the most frequent lemmas reveal the most important concepts in presidential programs, 10 lemmas are common for both programs and the most significant concept is Україн - (Україна / україниі / український) (Ukraine / Ukrainian). Semantic analysis shows that the main concepts in Zelenskyi's program reflect the terms of internal policy. The text of Poroshenko's program is focused on both external policy (joining NATO and the EU) and internal policy. Quantitative measurements of pronouns are revealed by the most frequent pronoun in both presidential programs $\mathrm{Mu}$ (we). It indicates such tactics of self-presentation strategy as plurality which points on collective responsibility. Poroshenko's program provides metonymy ми - краӥна (we are country), which is wider and more indefinite because includes not only people but state structures, territory, resources etc. $\mathrm{N}$-grams analysis show an interesting point about syntax.

A corpus of parliament speeches transcripts was created with SkethEngine software. It provides finding out such linguistic features as surzhykisms, Russian words which are in Russian graphics, occasionalisms, barbarisms, gender forms, colloquialisms ans slang which indicate cultural and educational level of politicians, as well as their communicative tactics.

So, using NLP tools for quantitative method of text analyses allows to underline some interesting linguistic features about tactics and strategies of presidential programs which are not evident with manual research.

\section{SUMMARY}

The research is aimed at distinguishing linguistic features of presidential programs and parliament speeches transcripts which the corpus-based approach can reveal. The data was taken from official websites. For quantitative analysis of presidential programs TextusPro and AntConc were 
used. Discussion based on word occurrence frequencies, quantitative parameters of pronouns and $\mathrm{N}$-grams. The result shows the presidential programs tactics and strategies which are not evident with manual research. A corpus of parliamentary speeches transcripts was created with SkethEngine software. It provides finding out some linguistic features including slang which indicates cultural and educational level of politicians, as well as their communicative tactics.

\section{REFERENCES}

1. Adagbonyin A., Aluya I. Edem S.A corpus-based approach to the linguistic features in Nigerian and American presidential speeches. Journal of Linguistics, Language and Culture. 2016. Vol. 3. № 1. P. 1-27. URL: https://www.researchgate.net/publication/330666402_A_corpusbased_approach_to_the_linguistic_features_in_Nigerian_and_American_pre sidential_speeches.

2. Amaglobeli G. Types of Political Discourses and Their Classification. Journal of Education in Black Sea Region. 2017. Vol. 3. Issue 1. P. 18-24. DOI: 3.10.31578/jebs.v3i1.117.

3. Dijk van T.A. What is Political Discourse Analysis? URL: http://www.discourses.org/OldArticles/What\%20is\%20Political\%20D iscourse\%20Analysis.pdf.

4. Guerra C.H. Textual, intertextual and rhetorical features in political discourse: the case of President Obama in Europe. Revista de Lingüística y Lenguas Aplicadas. 2013. № 8. DOI: 10.4995/rlyla.2013.1175.

5. Kassarnig V. Political Speech Generation // eprint arXiv:1601.03313 (January 2016). URL: https://arxiv.org/abs/1601.03313.

6. Kayam O. The Readability and Simplicity of Donald Trump's Language. Political Studies Review. 2018. Vol. 16. Issue 1. P. 73-88. DOI: $10.1177 / 1478929917706844$.

7. Morawski L. Argumentacje, racjonalność prawa i postępowanie dowodowe. Toruń: Universytet Mikołaja Kopernika, 1988. $311 \mathrm{~s}$.

8. Savoy J. Lexical Analysis of Obama's and McCain's Speeches. Journal of Quantitative Linguistics. 2010. № 17(2). P. 123-141. DOI: 10.1080/09296171003643205.

9. Savoy J. Trump's and Clinton's Style and Rhetoric During the 2016 Presidential Election. Journal of Quantitative Linguistics. 2016. DOI: 10.1080/09296174.2017.1349358.

10. Walter D. A Presidential Debate in N-grams // Subjective Functions: blog (published: Wed 28 September 2016). URL: https://dswalter.github.io/.

11. Дорофєєва М.С. Категорія суб'єкта в політичній промові (на матеріалі виступів федеральних канцлерів ФРН повоєнного періоду) : автореф. дис. ... канд. філол. н. : 10.02.04. Київ, 2005. 23 с. 
12. Кондратенко Н.В. Український політичний дискурс: Текстуалізація реальності: монографія. Одеса : Чорномор'я, 2007. 156 с.

13. Надель-Червинская М., Червинская А. Язык и сознание: номенклатура и феня (уголовно-партийный жаргон как коммуникативная форма «советской зоны»). Тернополь : Studia methodologica, 2009. $102 \mathrm{c}$.

14. Таран О.С. Сугестивні потенції сленгізмів в українських дискурсах // Ucrainica VI. Současná Ukrajinistika. Problémy jazyka, literatury a kultury: Sborník vědeckých článků. Olomouc : Univerzita Palackého v Olomouci, 2014. P. 168-171.

15. Таран О.С. Сленгизмы в политическом дискурсе (на материале украинских телевизионных ток-шоу). Вестник Прикамского соииального института. Филология. Пермь, 2013. № 2 (60). С. 42-48.

16. Харитонова Д.Д. Український політичний дискурс: когнітивносемантичні та прагмакомунікативні виміри : дис. ... канд. філол. н. : 10.02.01. Київ, 2018. 212 с.

\section{Information about the author: Taran O.S., \\ $\mathrm{PhD}$ (Philological Sciences),} Associate Professor at the Department of Applied Linguistics

Lviv Polytechnic National University 12, Stepan Bandera str., Lviv, 79013, Ukraine 